\title{
Environmental protection policies at craft villages in Hanoi in the context of sustainable development
}

\author{
Thanh Ly Nguyen ${ }^{1, *}$, Thi Bich Hanh Nguyen ${ }^{1}$, Thi Hoa Nguyen $^{2}$, and Vien Lan Huong Le ${ }^{3}$ \\ ${ }^{1}$ Graduate Academy of Social Sciences, No. 477, Nguyen Trai str., Thanh Xuan District, Hanoi City \\ 10000, Vietnam \\ ${ }^{2}$ Journal of Social Science Manpower, No. 477, Nguyen Trai str., Thanh Xuan District, Hanoi City, \\ 10000 , Vietnam \\ ${ }^{3}$ Vietnam Medical Military University, No. 160, Phung Hung, Ha Dong District, Hanoi City, 10000, \\ Vietnam
}

\begin{abstract}
Craft village is one of the distinct features of rural areas and an important factor in industrial and secondary manufacturing zones and subzones in Vietnam. Craft village, in nature, is a guild within a village who earn their living through non-agricultural activities. Craft village has been long preserved and developed with various characteristics including production subject (artisan); produce (featured by sophistication and arts); natural condition and specific technological process. In the context of industrialization and modernization being interwined with sustainable development, this article provides an insight into environmental protection policies applied to craft villages in Hanoi in order to understand the situation of executing environmental protection policies for craft villages in Hanoi; to point out challenges in formulating and implementing the policies; to therefore propose measures to develop the policies and enhance the implementation effectiveness. 1 Introduction
\end{abstract}

\section{Introduction}

Craft village is one of the distinct features of rural areas and an important factor in industrial and secondary manufacturing zones and subzones in Vietnam. Craft village, in nature, is a guild within a village who earn their living through non-agricultural activities. Craft village has been long preserved and developed with various characteristics including production subject (artisan); produce (featured by sophistication and arts); natural condition and specific technological process. Legally, according to Article 5, Decree 52/2018/ND-CP dated April $12^{\text {th }} 2018$ on development of rural sectors and occupations, a craft village is recognized by: (1) involving at least $20 \%$ of the household participating in rural trades; (2) operating constantly for at least two years; (3) meeting all legally-bounded environmental protection requirements. A traditional craft village must be a craft village with its traditional trades satisfying 3 criteria: a) the craftsmanship has existed in the locality for more than 50 years: b) the products are characterized by cultural and traditional features: $c$ )

*Corresponding author: nguyenly262@gmail.com 
the craftsmanship is associated with the fame of one or more artisans or a craft village.

The capital city of Hanoi is a national political and administrative hub, a center of culture, science, education, economy and international exchanges as well as a cradle of famous trades, craft villages and streets. According to 2019 statistics, Hanoi had the biggest number of craft villages with 1,350 trade villages including 308 craft villages and 12 traditional craft villages, accounting for more than $60 \%$ of its total villages. Every year, the villages manufacture a large number of products various in types and designs, greatly contributing to local and national economic and cultural development. Apart from their economic and cultural benefits, craft villages, with the production activities marked by low technological level and huge amount of unprocessed waste, are the main cause of alarming environmentalal pollution.

In the context of industrialization and modernization being interwined with sustainable development, this article provides an insight into environmental protection policies applied to craft villages in Hanoi in order to understand the situation of executing environmental protection policies for craft villages in Hanoi; to point out challenges in formulating and implementing the policies; to therefore propose measures to develop the policies and enhance the implementation effectiveness.

\section{Research methods}

On the basis of studying sustainable development theories, the research group utilizes the following methods: (1) statistical method and analysis of available legal documents, local and state reports; (2) Participatory Rural Appraisal (PRA) of directly affected subjects of the policies such as local authorities and trade practitioners; (3) field survey of a representative craft village; (4) Strengths, Weaknesses, Opportunities, and Threats Analysis (SWOT).

\section{Results}

Sustainable development is a topic of global interest. The concept of sustainable development has its birth dated back from the environmental protection movement in the early of 1970s, after a number of international conferences in Stockhon (1972), Belgrade (1975), Tbilisi (1977), Moscow (1987), Rio de Janeiro (1992), and Johannesburrg (2002), all with the basic goal of protecting the environment and ensuring "development without destruction". Since 1972, in the report "Our Common Future”, the World Council of Environment and Development has set out sustainable development goals as "development that meets the needs of the present without compromising the ability of future generations to meet their own needs".

In Vietnam, the idea of sustainable development was noted in Decree 36-CT/TW dated June $25^{\text {th }} 1998$ of the Politburo on enhancing environmental protection in the national industrialization and modernization and highlighted in many documents of the Vietnam Communist Party afterwards. Implementing the Party guidelines and policies, the State has issued a number of legal documents about sustainable development, especially the introduction of 1994 Environment Protection Law and many other sub-law documents. These documents all stressed the application of scientific and technological advances in environmental protection; policies on the exploitation and utilization of resources for industrial development; as well as solutions to protect the environment in the context of sustainable development. In realizing the Party's guidelines, such legal documents as 2013 Law on Land, 2010 Law on Minerals, 2013 Law on Natural Disaster Prevention and Control, 2014 Law on Environmental Protection, 2010 Law on Economical and Efficient 
Use of Energy... has been promulgated to build a fundamental legal framework for the national strategy of environmental protection, creating an economy-society-environment trilemma for sustainable development.

The existence and diverse development of craft villages in Vietnam have been part of the requirement of sustainable development basing on 3 main pillars: sustainable economic development, sustainable social development and environmental protection. Within the scope of craft activities, sustainable development goals are determined as follows: (1) sustainable economic development means that all production and business activities of a craft village develop with high effectiveness and productivity; (2) sustainable social development means that those activities abide by the laws, uphold cultural identities and values, positively contribute to the society and ensure interests of participants; (3) sustainable environmental development means that production and business activities of a craft village are carried out in parallel with environmental protection.

Researching the environmental protection policies at craft villages in Hanoi needs further investigation, including observing environmental protection policies at macro level (nationalwide) and in terms of trade, and regarding environmental protection policies at some particular villages. In order to map out measures for the betterment of policies and enhancement of the implementation process, it is necessary to evaluate the current situation of developing and executing environmental protection policies at craft villages in Hanoi in the following aspects: (1) scientific and technological advancement in production activities, (2) exploitatiton and utilization of resources, (3) waste treatment and pollution prevention and control.

In 2013 Decision 14/QD-UBND on approving the Master Plan for the Development of Hanoi's trade and craft village by 2020, with a vision to 2030, Hanoi People's Communittee highlighted the goals that are in close association with the three aforementioned contents. With regards to scientific and technological advancement in production activities: Hanoi aims to "further provide financial support for trade promotion, training, scientific and technological renovation, as well as to improve environment at craft villages" with the environmental protection solution of "encouraging clean production with technologies that minimize pollution". With respect to production materials, the city aims to "reasonably plan, exploit and effectively use resources", "to build resource re-development plan, especially materials for products of high demand". As regards waste treatment and pollution prevention and control, Hanoi is to "further invest into pollution treatment with greater priority given to craft villages that yield higher socio-economic effectiveness". This fact clearly demonstrates that Hanoi leadership has been fully aware of the close-knit relationship among scientific and technological progress, practical resource planning and exploitation and pollution prevention and control, in an attempt to achieve socio-economic development and environmental protection goals, heading towards sustainable development in the context of international integration.

Firstly, scientific and technological development in production

There has been a long-lasting history that most craft villages are featured by handicraft production, which is passed from generation to generation. In the context of industrialization, modernization and global economic integration, innovating technology and applying scientific advancement in production to solve economic and environmental puzzles are recognized as a key resolution, becoming a vital factor of craft villages. Being perfectly aware of its importance, Vietnam government has promulgated a quantity of policies encouraging scientific and technological development such as establishing funds to support the research, application, transfer and renovation of science and technology. The city of Hanoi has also issued various documents related to scientific and technological development policies.

It is shown in the policy implementation that over the past years integrating scientific 
and technological development in production activities of Hanoi craft villages has not only unlocked economic puzzles but also opened doors to environmental protection. Take Bat Trang Ceramic Village as an example, a leading unit that has enhanced economic effectiveness and minimized environmental pollution by renovating and applying scientific and technological advances in production. In the past, the manufacturing process of pottery and porcelain products mainly involved manual framing and decorating, and then baking in coal-heated kilns (Dung, Bau, Tuynen, Hop), therefore, releasing hazardous gasses such as $\mathrm{CO} 2, \mathrm{CO}, \mathrm{SO} 2$, Nox and dust. Especially, the production of coloring materials and color enamel needs oxide colors or clay and several rare metals which contains zinc and other radiative elements, leading to severe pollution and causing great damage to people health. According to a health survey in Bat Trang, of 223 people asked 76 had respiratory diseases and 23 had tuberculosis. Additionally, 70\% of cancer patients in Hanoi hospitals were Bat Trang locals in 1996 (S. Kim, 2002:15). At present, there are not many Bat Trang ceramic products made by hands. Instead, most are manufactured by modern framing, plaster printing, enamel atomizing and grinding technologies. Gas kilns are now used with chinneys 3 or 4 times higher than old ones. Exhaust gas does not contain dust and SO2, contributing to energy saving, limiting $\mathrm{CO}$ releases and boosting economic effectiveness.

A number of handicraft villages in Hanoi, which once caused pollution with noise, dust, organic solvent and solid waste, have now made efforts to renovate and applying modern technologies to production, contributing to enhancing productivity, product quality and pollution control. A typical example is Van Ha Carpentry Village. In the past most households used manual labor or old-generation semi-automatic sculpture machines, which was inefficient and labor-intensive. Nowadays, there are many craftsmen inventing simple motorized machines such as paint stirring machine; investing in a high-tech machine of carving four and eight automatic wooden chisels, featuring automatic chiselling of all product details. Such efforts have resulted in increasing product uniformity, lowering costs, enhancing competitiveness, and protecting human health as not in direct contact with wood dust.

Quang Nguyen Toothpick Village (Ung Hoa District) has used new technologies in material drying instead of the traditional way of drying and eliminating mold. Rattan and bamboo handicraft villages have applied carbon sequestration techniques, wood kilns and surface coating, thereby, not only shortening manual stages, improving productivity, reducing production costs, increasing product competitiveness, but also contributing to freeing up labor power and improving the environment. Wool weaving villages of $\mathrm{Y} \mathrm{La}, \mathrm{La}$ Duong, La Noi and La Phu (Hoai Duc District, Hanoi) have invested in upgrading wool looms with computer programming technology and automatic production line to increase labor productivity, save production costs, reduce environmental pollution, and increase income for workers.

Lacquer Craft Village, Duyen Thai Commune (Thuong Tin District, Hanoi) has applied new technologies in pressing energy pellets and creating core. Bich Hoa Craft Village (Thai Oai District), An Thuong (Hoai Duc District) has combined the anaerobic decomposition technology with the recovering biogas to create renewable energy to produce rice paper rolls. Van Phuc Silk Handicraft Village has shifted from manual production to modern weaving machines which can perform various tasks such as silk weaving, dyeing and embroidering thanks to already-installed program, resulting in labor saving, higher economic productivity and environmental protection. The villages of Phu Yen (Phu Xuyen District), Co Nhue (Bac Tu Liem District) ... have also used specialized machines in sewing. Wool weaving craft villages of Y La, La Duong and La Noi (Ha Dong District) have utilized weaving machines with built-in computer programs and automatic production lines. Lacquer Craft Village in Duyen Thai Commune (Thuong Tin District) has replaced manual production with the modern technology of pressing energy tablets and creating 
core.

With a view to keeping pace with science and technology, famous craft villages such as Da Sy Forging Village; Rua Thuong; Gia Vinh; Rua Ha; Du Tien; Phung Xa metalwork villages, etc., have used modern equipment and applied closed fuel treatment stages into their production, which not only increases labor productivity, but also improves product quality, consequently contributing to reducing the environmental pollution. Craft villages, therefore, have put hundred-ton machine tools, punching machines, and plating tanks into use, creating closed production lines and expanding their production scale into the level of workshops. Particularly, for a few recent years, 40 plating tanks have been erected, which allows them to form a closed production line with modern technology and develop into industrial clusters. The innovation of technology and equipment has contributed to improving economic efficiency, reducing product costs, improving models, increasing competitiveness both domestically and externally, minimizing harm to the environment, and especially offering sustainable solutions to craft village environment.

However, there exist a number of difficulties and shortcomings in developing science and technology in the production and business of craft villages when handling three elements of sustainable development, namely economy, society, and environment. This involves such factors as capital, technological research, and creation capability, science and technology application; product characteristics; environmental protection standards, etc. For example, Ha Thai Lacquer Craft Village has replaced production materials, switching from internally produced paint to an imported paint with a volatile solvent, reducing production time and cost on the one hand, increasing the risk of environmental damage, on the other hand. The Industrial Environmental Protection Association has sounded a note of caution about the fact that in the composition of the paint solvent, there are chemicals causing carcinogens, memory and vision loss, and especially respiratory diseases. It is also noted that handicraft villages often use chemicals, especially sulfur powder. It is estimated that each ton of rattan and bamboo has to go through 5 drying times, totaling $10 \mathrm{~kg}$ of sulfur. There is no doubt that burning sulfur involves environmental pollution (N. Hoang, 2003: 4). Thus, when applying science and technology into business and production in a trade village, besides the immediate economic efficiency, design, competitiveness in the market, the long-term solutions to possible adverse impacts on local habitats are also taken into consideration.

Secondly, the policy of rational exploitation and raw material use for production and business activities of craft villages in Hanoi.

The source of material not only determines the economic value and product characteristics of a trade village, but also is a major factor affecting the sustainable development of the village's environment at the stage of raw material exploitation and utilization. Therefore, the policy on environmental protection in craft villages always aims at proper exploitation and utilization of raw materials for production and business activities.

The policy on exploiting and using raw materials for the production and business of craft villages in Hanoi is reflected in many strategies and plans for socio-economic and industrial development. This, at the same time, is specified in many programs and schemes to encourage the development of craft villages. Policies of rational exploitation and use of raw materials for production and business activities of craft villages in Hanoi can be assessed on a number of basic contents: rational exploitation of raw materials; proper use of raw materials; raw materials recycling; and alternative sources of materials.

That craft villages in Hanoi have varied in production and business lines results in different inputs of materials for production. Typical examples are as follows: 
Table 1. Some main raw materials of Hanoi craft villages (Source: Survey of the research team).

\begin{tabular}{|c|c|c|c|}
\hline Industry & Typical craft villages & Raw materials & Origin of raw materials \\
\hline Ceramics & $\begin{array}{l}\text { Ceramic villages: } \\
\text { Tràng; Phú Sơn; Tô } \\
\text { Hiệu; Kim Lan, etc }\end{array}$ & $\begin{array}{l}\text { Clay, kaolin (a } \\
\text { white clay, high } \\
\text { heat resistance) }\end{array}$ & $\begin{array}{l}\text { From Hải Dương, Quảng } \\
\text { Ninh, Phú Thọ }\end{array}$ \\
\hline $\begin{array}{l}\text { Bamboo and } \\
\text { Rattan }\end{array}$ & $\begin{array}{l}\text { Bamboo and Rattan } \\
\text { villages: Phú Vinh; } \\
\text { Lam Điền; Bài Trượng; } \\
\text { Phụ Chính; Đồng Lư; } \\
\text { Van La conical hat } \\
\text { village, etc }\end{array}$ & $\begin{array}{l}\text { Bamboos, } \\
\text { neohouzeaua, } \\
\text { rattan, wood, } \\
\text { rush, grass, giang } \\
\text {.. most of which } \\
\text { are exploited from } \\
\text { natural forests. }\end{array}$ & $\begin{array}{l}\text { From } \\
\text { mountainous and central } \\
\text { provinces, and some are } \\
\text { imported. }\end{array}$ \\
\hline $\begin{array}{l}\text { Weaving, } \\
\text { sewing and } \\
\text { embroidery }\end{array}$ & \begin{tabular}{lr}
\multicolumn{3}{l}{ Van Phuc silk weaving } \\
village; Thang Loi \\
embroidery village; \\
Trach Xa & sewing \\
village; Dai & Dong \\
embroidery & village; \\
Phung Xa & weaving \\
village, etc &
\end{tabular} & Silk and cotton & $\begin{array}{l}\text { Silk from some silkworm } \\
\text { raising villages, but most } \\
\text { are imported }\end{array}$ \\
\hline $\begin{array}{l}\text { Dó paper } \\
\text { manufacturing }\end{array}$ & $\begin{array}{l}\text { Dó paper making } \\
\text { villages: Vân Canh, } \\
\text { Bưởi, Nghĩa Đô, etc }\end{array}$ & Dó paper trees & $\begin{array}{l}\text { Grown in Lai Châu; Yên } \\
\text { Bái; Phú Thọ; Lạng Sơn; } \\
\text { Hà Tây; Hòa Bình; Quảng } \\
\text { Ninh; Quảng Nam. }\end{array}$ \\
\hline
\end{tabular}

Craft villages in Hanoi are mostly concentrated in a number of industries such as ceramics, rattan, silk, Dó paper making. It is these villages that bring great economic benefits and preserve the cultural traditions of the capital. It is worth noting that production materials of these craft villages are mostly not produced in Hanoi but from other regions of the country or imported from overseas. The raw materials in ceramic villages are mainly imported from Northern provinces, whose sources of clay and kaolin are of very high quality. Particularly, Hanoi rattan villages use about 6,700 tons of raw materials mainly imported from Northern and Central provinces. As regards silk and cotton for weaving and sewing villages, besides buying from a number of mulberry farming and silkworm raising villages in Hanoi, the rest is imported from abroad. According to the statistics from the General Department of Customs, with regard to Vietnam's textile and apparel industry in 2019: nearly $90 \%$ of fabrics are imported from China, Taiwan, South Korea, etc.; $80 \%$ of yarn is imported from the US, West Africa, India, and so on. Also according to the General Department of Customs, in 2018, Vietnam imported US \$ 23.91 billion of textile, leather and footwear raw materials, including cotton, textile fibers, fabrics, textile materials, garment, leather, and footwear, up 13.9\% compared to 2017 (Vietnam Textile and Garment Association, 2018).

The rational and economical use of raw materials in craft villages is always highlighted in development plans and strategies for craft villages. This, for example, is mentioned in the Master plan on development of craft and craft villages up to 2020, with a vision to 2030 under 2013 Decision No. 14 / QD-UBND. Accordingly, textile and garment craft villages are encouraged to "use of natural materials", and ceramic and craft villages must have a solution to "efficiently planning, exploiting, and using sources of materials". The economical use of materials for craft villages is highly dependent on production technologies and alternative sources of raw materials, which reduces the number of coal burners, switching to oil and gas incinerators in ceramic villages.

Though many attempts have been made to find alternative sources of raw materials, the 
material found are mostly auxiliary ones such as paints, dyes, detergent originating from China, which are sold rampantly in the market. For example, it is in textile dyeing and printing processes that chemicals and dyes such as Javen, $\mathrm{H} 2 \mathrm{O}, \mathrm{CH} 3 \mathrm{COOH}, \mathrm{H} 2 \mathrm{~S}$, acid dyes, sulfur dyes (stone, Na2S), etc., and a great amount of water used in the production stages cause environmental pollution. Detergent used in silk weaving villages, after cleaning, will discharge $25 \%$ of impurities; consequently, $1 \mathrm{~m}$ of silk weighing $80 \mathrm{~g}$ will discharge $20 \mathrm{~g}$ of impurities into the water (Vietnam Association for Nature and Environment Protection, 2004: 288).

The policy of renewable material sources, though of great concern, is still in a state of not being able to regenerate. Craft villages are always in insufficient supply. Some raw materials such as kaolin, thus, become expensive and overexploited (HMT Le, TNPham, TBNguyen, NXNguyen, VHTNguyen, 2013: 105). Another problem is the scarcity of materials. For instance, Dó paper trees, though widely distributed, has a small number of individuals, and is on the verge of extinction due to exploitation and habitat destruction. (Critical condition class V) (Ministry of Science, Technology, and Environment, 1996: 35).

Thirdly, waste treatment system to prevent and combat environmental pollution.

The development of craft villages also leads to an upsurge in pollution ranging from soil, water, air, noise, vibration, humidity, etc. With a large amount of toxic waste from production and business activities in craft villages, the living environment and human health have been seriously affected.

Table 2. Pollution characteristics from the production of some types of craft villages (Source: National Environment Reports).

\begin{tabular}{|c|c|c|c|c|}
\hline \multirow{2}{*}{$\begin{array}{c}\text { Types of } \\
\text { production }\end{array}$} & \multicolumn{4}{|c|}{ Types of waste } \\
\hline & Emissions & Wastewater & Solid waste & $\begin{array}{c}\text { Other types of } \\
\text { pollution }\end{array}$ \\
\hline $\begin{array}{l}\text { 1. Food and food } \\
\text { stuff processing, } \\
\text { animals } \\
\text { husbandary and } \\
\text { slaughter }\end{array}$ & $\begin{array}{l}\text { Dust, } \\
\mathrm{SO}_{2}, \\
\mathrm{CH}_{4}\end{array}$ & $\begin{array}{l}\text { BOD, COD, } \\
\text { suspended } \\
\text { solids, toatal N, } \\
\text { total P Coliform }\end{array}$ & $\begin{array}{l}\text { Coal slag, } \\
\text { solid waste } \\
\text { from raw } \\
\text { materials }\end{array}$ & $\begin{array}{l}\text { Humidity, } \\
\text { thermal } \\
\text { pollution }\end{array}$ \\
\hline $\begin{array}{lr}2 . & \text { Weaving, } \\
\text { dyeing, } & \text { and } \\
\text { tanning } & \end{array}$ & $\begin{array}{l}\text { Dust, } \mathrm{CO} \text {, } \\
\mathrm{SO}_{2}, \mathrm{NO}_{\mathrm{x}}, \\
\mathrm{CH}_{4}, \text { alkaline } \\
\text { and acid gas, } \\
\text { solvent }\end{array}$ & $\begin{array}{l}\text { BOD, COD, } \\
\text { coloring, Total } \\
\mathrm{N} \text {, chemicals, } \\
\text { bleach, Cr6 + } \\
\text { (tanning) }\end{array}$ & $\begin{array}{l}\text { Coal slag, silk } \\
\text { thread, } \\
\text { residue, rags } \\
\text { and chemical } \\
\text { packaging }\end{array}$ & $\begin{array}{l}\text { Humidity, } \\
\text { thermal, and } \\
\text { noise pollution }\end{array}$ \\
\hline $\begin{array}{l}\text { 3. Crafts } \\
\text { - Ceramics } \\
\text { - Lacquer, fine art } \\
\text { wood, stone craft }\end{array}$ & $\begin{array}{l}\text { - Dust, } \mathrm{SiO}_{2} \text {, } \\
\mathrm{CO}, \quad \mathrm{SO}_{2} \text {, } \\
\mathrm{NO}_{\mathrm{x}}, \mathrm{HF} \text {, } \\
\text { organic } \\
\text { substances } \\
-\quad \quad \text { Dust, } \\
\text { gasoline } \\
\text { vapor, } \\
\text { solvent, } \mathrm{Fe} \\
\text { oxide, } \mathrm{Zn}, \mathrm{Cr} \text {, } \\
\mathrm{Pb}\end{array}$ & $\begin{array}{l}\text { BOD, COD, } \\
\text { suspended } \\
\text { solids, color, } \\
\text { industrial grease }\end{array}$ & $\begin{array}{l}\text { Coal slag } \\
\text { (ceramics), } \\
\text { waste } \\
\text { products, and } \\
\text { chemical } \\
\text { residues }\end{array}$ & $\begin{array}{l}\text { Thermal } \\
\text { pollution } \\
\text { (ceramics) }\end{array}$ \\
\hline $\begin{array}{l}\text { 4. Recycling } \\
\text { - Paper recycling } \\
\text {-Metal recycling } \\
\text {-Plastic recycling }\end{array}$ & $\begin{array}{l}\text { - Dust, } \mathrm{SO}_{2}, \\
\mathrm{H}_{2} \mathrm{~S}, \text { alkaline } \\
\text { gas } \\
\text { - Dust, } \mathrm{CO}, \\
\text { metal gas } \\
\text { acid gas, } \mathrm{Pb} \text {, }\end{array}$ & $\begin{array}{l}-\mathrm{pH}, \mathrm{BOD}_{5}, \\
\text { COD, tồng } \mathrm{N} \\
\text { total } \mathrm{N} \text {, total } \mathrm{P} \text {, } \\
\text { coloring } \\
\text { - COD, grease, } \\
\mathrm{CN}-\text {, metal }\end{array}$ & $\begin{array}{l}\text { - Paper dust, } \\
\text { impurities } \\
\text { from scrap, } \\
\text { packaging } \\
\text { chemicals } \\
\text { - Coal slag, }\end{array}$ & $\begin{array}{l}\text { Thermal } \\
\text { pollution }\end{array}$ \\
\hline
\end{tabular}




\begin{tabular}{|l|l|l|l|l|}
\hline & $\begin{array}{l}\text { Zn, HF, THC, } \\
\mathrm{HCl} \\
-\mathrm{D} \text { Dust, CO, } \\
\mathrm{Cl}, \quad \mathrm{HCl}, \\
\mathrm{THC}, \text { solvent } \\
\text { gas }\end{array}$ & total P, coloring & $\begin{array}{l}\text { rust, heavy } \\
\text { metal scrap } \\
\left(\mathrm{Cr}^{6+}, \mathrm{Zn}^{2+} \ldots\right) \\
-\mathrm{Labels} \text { are } \\
\text { not recycled, } \\
\text { metal parts, } \\
\text { rubber }\end{array}$ & \\
\hline $\begin{array}{l}5 . \quad \text { Building } \\
\text { materials, } \\
\text { quarrying }\end{array}$ & $\begin{array}{l}\text { Dust, CO, } \\
\mathrm{SO}_{2}, \quad \mathrm{NO}, \\
\mathrm{HF}, \mathrm{THC}\end{array}$ & $\begin{array}{l}\text { Suspended } \\
\text { solids, Si, Cr }\end{array}$ & $\begin{array}{l}\text { Coal slag, } \\
\text { slag, crushed } \\
\text { stone }\end{array}$ & $\begin{array}{l}\text { Thermal } \\
\text { pollution, noise, } \\
\text { vibration }\end{array}$ \\
\hline
\end{tabular}

Over the past years, the Party and the State of Vietnam have placed a high priority on environmental pollution treatment, including that in craft villages. This policy is reflected through laws and by-laws. Hanoi has issued many documents to realize the State regulations and organized to implement environmental protection for craft villages. The key issues identified by the city include: (1) assessment of craft village environmental pollution; (2) develop plans and invest funds to address craft village environmental pollution.

The People's Committee of Hanoi City has launched a project to support environmental impact assessment. Accordingly, craft villages, both applying for and already recognized villages, are subject to environmental impact assessment under the Government's Decree No. 18/2015/ND-CP of February 14, 2015, supported by the City with VND 200 million / $01 \mathrm{craft}$ village, in order to implement current environmental impact assessment.

2019 statistics show that out of 308 craft villages and traditional craft villages recognized by Hanoi People's Committee, 233 villages (accounting for 75.65\%) are subject to assessment of environmental impact according to the provisions of the Government's Decree No. 18/2015/ND-CP dated February 14, 2015, including 11 lacquer and pearl mosaic craft villages; 83 bamboo and rattan handicraft villages; 23 forest products processing villages; 25 textile villages; 9 leather and footwear villages; 13 metal villages; 15 sculpture villages; 55 agricultural products and foods processing villages (Hanoi People's Committee: 2019). Implementing the project "Protection of handicraft village environment in Hanoi city to 2020 and orientation to 2030", Hanoi Department of Natural Resources and Environment has surveyed, sampled and analyzed the environment in 65 craft villages. The results show that $60 / 65$ handicraft villages are polluted. Most of the craft villages do not have satisfactory infrastructure systems, especially inadequate wastewater drainage systems.

The majority of wastewater from craft villages is untreated and discharged into ponds and lakes with very high levels of pollution. Specifically, in terms of water pollution, there are 40 craft villages classified as severely polluted, 17 as polluted, and 8 non-polluted. In terms of air pollution, there are 12 craft villages classified as severely polluted, 10 as polluted, and 43 as unpolluted. In terms of soil pollution, which is assessed in $37 / 65 \mathrm{craft}$ villages, there are 3 villages classified as severely polluted, 2 polluted, and 23 as nonpolluted.

The most polluted villages in Hanoi are those which process agricultural products, food, and foodstuff. For instance, craft villages in Duong Lieu, Minh Khai, and Cat Que communes of Hoai Duc district have been included in the list of which are not encouraged to develop due to their conversion from processing starch to food processing (confectionery). And those which cause environmental pollution are moved to Duong Lieu Techmart.

Specifically, in terms of water environment, 40 craft villages have been listed as severely polluted, 17 polluted, 8 unpolluted; in terms of air environment, 12 craft villages have been listed as severely polluted, 10 polluted, 43 unpolluted; in terms of soil environment (among 37/65 craft villages assessed), 3 craft villages have been listed as 
severely polluted, 2 polluted, 23 unpolluted. The craft villages that cause most environmental pollution in Hanoi process agricultural products, food, foodstuff like the ones in the communes of Duong Lieu, Minh Khai, and Cat Que, Hoai Duc District. Hanoi People's Committee has included them in the list of handicraft villages not being encouraged to develop due to the conversion from processing starch to foodstuff (confectionery) and moved large enterprises and production households that cause environmental pollution to Duong Lieu Production Cluster.

Having assessed the environmental impacts in craft villages, Hanoi has implemented a number of projects on treating wastewater in large-scale craft villages such as Cau Nga Wastewater Treatment Factory (which came into operation in October 2016 in Duong Lieu Production Cluster, Hoai Duc district) with a daily capacity of 20,000m3; completed Wastewater Treatment Factory (which came into operation in 2019) in Son Dong commune, Hoai Duc district with a daily capacity of $8,000 \mathrm{~m} 3$ treating wastewater from the 5 communes of Dac So, Yen So, Son Dong, Duc Gang, and Tien Yen; speeded up the construction of a centralized wastewater treatment system in the textile \& dyeing village of Phung Xa commune, My Duc district (with a daily capacity of 500m3) (according to data from Hanoi Department of Natural Resources and Environment, 2019).

In addition, the city has called for investment in environmental treatment projects for craft villages including 8 projects for treating wastewater and waste in craft villages located in Quoc Oai, Me Linh, Hoai Duc and Thuong Tin districts with a total estimated investment capital of 569 billion dong and called for investment in 48 industrial clusters to develop craft villages in Phuc Tho, Thach That, Quoc Oai, Hoai Duc, Thanh Oai, Thuong Tin, Ung Hoa, Phu Xuyen, Chuong My, Thanh Tri and Ha Dong districts with a total estimated investment capital of nearly 9,000 billion dong. In terms of collecting and treating solid waste in craft villages, this process is now done by the self-managed collection teams under direct management of Communes People's Committes or assigned to the villages for selfmanagement or done by the sanitation units; self-balancing on the basis of fee collection for environmental cleaning.

The socialization models for pollution prevention and control in craft villages are currently an effective direction in the capital city with the involvement of relevant levels/sectors and the participation of community groups in protecting the environment in craft villages. The city has encouraged production activities towards building eco-friendly craft villages; built an automatic monitoring system to control the environmental pollution in craft villages; studied the feasibility and built a socialization model to solve wastewater pollution in craft villages; and formulated expenditure for treating waste water in craft villages.

Besides those positive aspects, the environmental protection policies in the city reveal some limitations such as the failure to keep up with the speed and scale of development in craft villages, the sanctions applied not strong enough to ensure deterrence against environmental violations, which has greatly affected the sustainability of craft villages in Hanoi.

A survey of 40 communes in Hanoi showed that about $60 \%$ of the communes were seriously polluted by production activities. These are mainly located in such groups of craft villages as Huu Hoa (processing vermicelli, rice cakes) where wastewater from soaking, deterent powder, together with wastewater from livestock and human life all flow directly into the local sewage system; Phu Dien and Thuong Cat craft villages (producing tofu) where wastewater from tofu production is also discharged into the communal sewer system causing environmental pollution. In weaving and dyeing villages such as Van Phuc, Trieu Khuc, etc., due to a lot of water, chemicals and dyes used in the production process, the wastewater is filled up with natural impurities from fibers, dirt, oil, waxes, nitrogencontaining compounds, pectin during bleaching, silk bleaching, and chemicals used in 
fabric processing stages such as starch paste, dyes, detergents. Between 10-30\% of the dyes and chemicals used is discharged with the waste (source: Vietnam Association for Nature and Environment Protection, 2004, p. 289). For metal recycling villages such as Phung Xa, Lieu Noi and the likes, waste has been discharged from smithy and smelting furnaces into the environment, causing soil and water contamination of heavy metals, very high $\mathrm{Cu}, \mathrm{Pb}$ and $\mathrm{Zn}$ content in wastewater exceeding the permitted standard by many times, especially electroplating wastewater with large fluctuating level of $\mathrm{pH}$, heavy metals and many chemicals of toxic inorganic compounds like acid, caustic soda, heavy metal salts (Source: Vietnam Association for Nature and Environment Protection, 2004, p. 288).

In addition, one of the current issues of concern in craft villages is air pollution reported in most groups of craft villages, especially those producing construction materials, carpentry, pottery, plastic and metal recycling, etc. The production in most of these craft villages is manual, using charcoal and coal which causes air pollution from dust and steam, $\mathrm{SO} 2, \mathrm{CO} 2, \mathrm{CO}$ and NOx. Among these pollutants, $\mathrm{CO} 2$ and NOx cause the greenhouse effect. These toxic gases are also generated during anaerobic decomposition of organic compounds in wastewater and solid organic waste. Dust in the air arises from classifying, preliminary processing, rusting, cooking, rolling, pulling, especially the nearby areas of steel foundries, where dust content exceeds the permitted standard by 10-15 times. In these craft villages, the dust usually contains metals, mainly iron oxide with the level of up to 0.5 $\mathrm{mg} / \mathrm{m} 3$, making the air smelly. In the air of these villages, toxic chemicals such as $\mathrm{Cl}, \mathrm{HCN}$, $\mathrm{HCl}, \mathrm{H} 2 \mathrm{SO} 4, \mathrm{SO} 2, \mathrm{CO}, \mathrm{NO}$ are always found, with even a very small but frequently present content causing a significant impact on community health.

In the craft villages, not only are the water and air sources in the craft villages polluted, noise issues are also alarming. This kind of pollution is typical in carpentry, forging, and carving villages, where the noise level exceeds $85 \mathrm{~dB}$, especially in the nearby areas of dualtimed sawn, lumber and rattan sawing machines with noise level exceeding $95 \mathrm{~dB}$ (The acceptable level is in the range of $30-70 \mathrm{~dB}$ ).

According to the findings of the study on the real situation of implementing environmental protection policies in Hanoi craft villages, some challenges have been as follows:

Firstly, the policy of developing science and technology is not clear enough to have a direct impact on production and business activities in craft villages. The fragmented, spontaneous nature of access to science and technology is found in most craft villages. Meanwhile, the application of science and technology in craft villages still puts economic goals first instead of proactively preventing and solving environmental pollution. The application of advanced technology for craft villages also faces difficulties in preserving the cultural value of traditional products. Hanoi's solutions in the master plan on development of craft and craft villages up to 2020 , with a vision to 2030 are only limited to encouraging production households to apply new technologies under the support and direction of the city's functioning bodies, but not finding measures and capital sources of strategic investment for craft villages. Scientific and technological development requires a large capital of investment, while the city's budget is unadequate and the craft villages' access to capital is still limited. Therefore, when implementating policies, uncomprehensive and delayed improvements in science and technology pose a risk of unsafety to craft villages and the people's environment.

Secondly, the exploitation and use of raw materials for production and business activities of craft villages in Hanoi have posed great challenges due to the shortage of raw materials in most craft villages. In the process of seekng raw materials, excessive exploitation of raw materials, inproper planning and development of alternative raw materials have seriously affected the environment and sustainable development. Despite great efforts in economical and proper use of raw materials, craft villages are always 
suffering from insufficient supply, resulting in higher prices of raw materials.

Thirdly, classifying handicraft village groups and assessing environmental impacts of craft villages have been carried out in accordance with the stages of development planning of craft and craft villages in Hanoi. However, solving environmental pollution in these villages has not been thoroughly implemented with limited results. Solving environmental problems requires investment from policies on planning capital sources, but with the spontaneous, small and dispersed production of craft villages, the application of comprehensive solutions to classifying and solving environmental pollution faces a number of difficulties.

Solutions to build, complete policies and improve the effectiveness of the implementation of environmental protection policies for craft villages in Hanoi

The difficulties and challenges in the process of sustainable development of craft villages in general and protection of craft village environment in Hanoi in particular not only stem from policy formulation but also in the process of implementing environmental protection policies in craft villages. Therefore, solutions to environmental protection in Hanoi craft villages need to be considered comprehensively from policy formulation to policy implementation as follows:

Firstly, developing science and technology towards reducing environmental pollution in craft villages requires more specific policies including:

- Enhancing policies on transferring technology from developed countries via tax and credit tools, etc. Importing used equipment needs to be carefully considered in order not to turn craft villages into technological waste sites.

- Completing policies to promote scientific and technological R \& D for craft villages through funding research studies; giving incentives and rewards to scientific and technological applications to production and business in craft villages.

- Issuing policies to call for and attract investment into scientific and technological development of craft villages.

- Classifying existing crafts, it is necessary to make an objective assessment based on the evidence of which groups and stages that can apply scientific and technological innovation to replace manual labor; thereby providing practical measures to support production and business activities in craft villages.

Secondly, regarding exploitation and use of raw materials for production and business activities in craft villages, it is necessary to:

- Increasing coordination with localities to make full use of local raw materials by linking investment in local production workshops to exploit local labor and reduce transportation costs, which helps to create a chain of supplying raw materials for craft villages in Hanoi.

- Concretizing policies on support and incentives, especially prioritizing to build material areas, exploit and process raw materials for production in craft villages.

- Developing a special mechanism meeting the requirements and reality of Hanoi craft villages to have policies to directly support and consume raw materials and semi-finished products in order to encourage localities to pay attention to developing and supplying "input" materials to craft villages in Hanoi.

Thirdly, regarding policies on environmental impact assessment and waste treatment system construction to prevent and fight environmental pollution, it is necessary to:

- Continuing to assess environmental pollution impacts in Hanoi craft villages by craft and business groups in order to seek solutions to prevent and fight environmental pollution in an appropriate and effective way.

- Classifying craft villages by degree of pollution based on findings of environmental impact assessment, thereby providing financial support policies for environmental solutions in those villages. 
- Planning the craft village space integrated with environmental protection and based on special characteristics of each craft village and craft group; move the units that cause serious pollution out of residential areas.

- Developing legal sanctions framework, policies to handle violations by craft villages that cause environmental pollution; binding the responsibilities of production and business households in craft villages with the ecological environment protection through legal commitments.

\section{Conclusion}

In the process of global integration, environmental protection is an indispensable requirement for the sustainable development of craft villages in Hanoi in particular and Vietnam in general. The research and field surveys done in craft villages in Hanoi show that over the past time the development of policies on environmental protection for craft villages has been paid much attention and implemented in various stages by the local authority. However, it is proved that there have existed many obstacles and shortcomings posing major challenges in the execution of environmental protection policies. These obstacles and shortcomings are not only due to limitations in policy formulation but also difficulties in the implementing process. Therefore, it is required for Hanoi to develop comprehensive solutions from formulation policies to enhancing the effectiveness of policy implementation based on three main contents: developing science and technology towards environmental pollution control; conducting rational exploitation and utilization of production materials; enhancing environmental impact assessment to build waste treatment systems to prevent environmental pollution in craft villages.

\section{References}

1. "Our Common Future" report. United Nations Human Environment Workshop (World Council on Environment and Development (WCED), Stockholm, 1972)

2. S. Kim, Knowledge and technology 148, 15 (2002)

3. Technology and Environment, Report on findings from surveys, observation, updated environmental data in some key craft villages in Ha Tay (Ha Tay Department of Science, 2001)

4. H.M.T. Le, T.N. Pham, T.B. Nguyen, N.X. Nguyen, V.H.T. Nguyen, Journal of Science and Technology 51(1), 101-106 (2013)

5. Ministry of Science, Technology and Environment. Vietnam Red Book (Science and Technology Publishing House, 1996)

6. Statement on requesting the City People's Council to issue a Resolution on some policies to encourage the development of rural industries and craft villages in Hanoi (Hanoi People's Committee, 2019)

7. Vietnam Association for Nature and Environment Protection. Vietnam, environment and life (National Political Publishing House, Hanoi, 2004)

8. N. Hoang, Science and Development 18, 4 (2003)

9. Report on assessment of environmental impact of craft villages in Hanoi (Hanoi Department of Natural Resources and Environment, 2019)

10. Textile and garment export strategy report (Vietnam Textile and Garment Association, 2018) 